\title{
THE REDISTRIBUTIVE EFFECTS OF MONETARY POLICY ACROSS GENERATIONS
}

\section{OLGA BONDARENKOa}

aNational Bank of Ukraine

Email: Olha_Bondarenko@bank.gov.ua

\begin{abstract}
The paper revises the redistributive channels of monetary policy transmission and their impact on income and wealth distributions in a New-Keynesian Overlapping Generations (OLG) model. The model mimics total asset holdings and earnings processes of several types of households across generations, based on their attitude to saving and income group. In this environment, expansionary monetary shocks stimulate capital and debt accumulation to a larger extent for middle-aged individuals, contributing to intergenerational inequality. Heterogeneity of labor income augments this effect, benefitting richer and more productive workers.
\end{abstract}

JEL Codes

D31, E12, E21, E52

Keywords monetary policy, wealth redistribution, overlapping generations, heterogeneous agents

\section{INTRODUCTION}

The conventional understanding of monetary policy entails its long-run neutrality with respect to real variables, such as output, consumption, and capital. From this perspective, the influence of monetary policy on the distribution of wealth is implicitly assumed to be negligible over the business cycle, as benefits earned during economic rebounds entirely offset any losses incurred during downturns. However, with asymmetric responses of aggregate expenditure and prices, when unanticipated contractionary interest rate changes tend to exhibit a more pronounced effect during expansions than recessions (Tenreyro and Thwaites, 2016), the validity of this statement becomes highly questionable.

Until recent years, central banks typically failed to properly consider the distributional consequences of monetary policy. An analysis based on representative agent models (RANK) was not able to capture and quantify the contribution of interest rate changes in reversing the downward inequality trend that dominated the 20th century. The sound of silence has now been broken, with central banks having to employ unconventional monetary policy tools in response to financial crisis, bringing discussion about the inequality they entail to new heights (Ohlsson, 2017; Constancio, 2017; Haldane, 2018). Nevertheless, the absence of a firm starting point, i.e. a clear-cut understanding of the impact of traditional monetary policy instruments, has flicked out of sight.

One might argue that wealth redistribution, or inequality in general, is not within a central bank's mandate, and rightly so. However, evidence that redistribution is a channel of aggregate stabilization, which policymakers intend to achieve, is becoming increasingly available. The intuition behind this is based on an argument outlined by Tobin as far back as 1982: debtors, who typically benefit from an expansionary policy, tend to consume more out of their disposable income than savers, who lose. Along with net wealth, other household characteristics, including age and income type, lead to asymmetries in responses to interest rate changes, and hence, amplify its effect on macroeconomic aggregates. Quantifying this impact on heterogeneous agents can deepen the understanding of aggregate responses, and hence, improve a central bank's approach to interventions. As the RANK model relies basically on a direct interest rate channel, it presupposes that real interest rate changes can generate a strong enough stimulus to boost aggregate expenditures. In contrast, heterogeneous agent (HANK) models show that the fine-tuning of the economy is far more complex, given that the income effect (instead of intertemporal substitution) plays a prominent role in shaping agents' decisions. As either substitution or income effects can be dominant during the various stages of a household's life, considering redistributive forces within the life-cycle framework can potentially assist in developing better policy advice.

A dynamic stochastic general equilibrium (DSGE) model, featuring heterogeneity of agents in the income, wealth, and age dimensions, is considered to be a suitable tool for modeling the reaction of markets to unanticipated shifts in monetary stance. Built on models elaborated in Heer and Maussner (2012), Andrés et al. (2018), it includes nine types of household, each consisting of 60 age cohorts (equivalent to 60 years of life, from the age of 20 to 80 ). In constructing other model components, the traditional New-Keynesian literature is followed. Income and wealth profiles of agents are 
calibrated using the Panel Study of Income Dynamics (PSID) for 2001 to 2015. The model simulations are performed in Matlab and Dynare 4.4.3 toolbox.

The rest of the paper is organized as follows. Chapter 2 provides an extensive literature review on the theoretical concept of monetary policy transmission to consumption. Chapter 3 presents the model. Chapter 4 specifies the calibration values. Finally, chapter 5 compares the model distributions and IRFs. Chapter 6 provides conclusions.

\section{LITERATURE REVIEW}

Effectiveness in reaching the objective of price stability depends crucially on timing and proper understanding of the underlying monetary policy transmission mechanism, based on analysis of channels propagating the impact of central banks actions.

The literature generally divides the transmission mechanism into two complementary views operating under different model setting, namely neoclassical (with perfect financial markets) and non-neoclassical, assuming the presence of financial market imperfections. The traditional neoclassical, or money, view lies in the heart of core macroeconomic models, elaborated in the mid-20th century. It entails three basic channels, through which monetary policy affects aggregate demand: direct interest rate channel; asset price effect, following from Jorgenson (1963) and Tobin (1969); intertemporal substitution channel, rooted in the Ando and Modigliani (1963) permanent income hypothesis; and exchange rate channel, described primarily by the model of Mundell (1963) and Fleming (1962).

The discussion on a parallel non-neoclassical, or credit, view has started when Bernanke and Gertler (1995) questioned the ability of traditional transmission mechanism to explain the evidence of how relatively small interest rate changes can generate relatively huge fluctuations in output. Standing on the assumption that external and internal financing are imperfect substitutes, this channel implies a considerable effect of monetary policy on the premium on external funds, leading to contraction of banks credit supply (bank lending channel), on the one hand, and deterioration of borrowers net worth (balance sheet channel), on the other.

Either view, however, disregard any distributional effects by adopting a representative agent. This approach can yet be questioned when confronted with the empirical studies that quantitatively evaluate the effect of monetary policy stance on the distribution of wealth.

Recent literature distinguishes five channels of monetary transmission, entailing redistributive consequences across economic agents. Heathcote et al. (2010) provide empirical evidence that earnings of households, belonging to opposite ends of the distribution, respond differently to business cycle fluctuations. While changes in labor income of 90th percentile are driven primarily by wage adjustments, earnings of 5th and 10th percentiles reflect unemployment rate developments, falling excessively upon these groups. Accompanied by labor market imperfections and varying extents of wage rigidity for high- and low-income households, these stylized facts give rise to earning heterogeneity channel of monetary policy. In so far loose financial conditions contribute to a larger decline in unemployment than to the growth in hourly wages, inequality is reduced.

Income heterogeneity channel is closely related to earnings heterogeneity, but encompass as well other sources of income, such as financial proceeds, dividends, and transfers from the government. It can potentially amplify or dampen reduction in inequality, outlined above, depending on households' primary sources of income. Whenever transfers from the government, having a countercyclical nature, occupy a larger share of households' budget, redistributive forces tend to decrease inequality. On the contrary, the presence of a substantial fraction of capital returns - a distinctive feature of income, received by rich economic agents - that grows faster than wages on the impact of interest rate cuts, augment negative impact on inequality by widening the gap between those in the top percentiles of distribution and in the middle ones. Gornemann et al. (2012), based on a NewKeynesian model with market incompleteness and labor market search and matching frictions, confirm an uneven effect of monetary tightening on households with different income structure due to a notable reduction in labor earnings and employment across firms.

Access to financial markets plays a crucial role in the financial segmentation channel, determining the timeline and succession of monetary policy impact on trading and nontrading agents. It contributes to an upswing in inequality, provided that households, connected and participating in financial markets, have higher average earnings than unconnected ones. Being able to respond first to changes in policy stance, they benefit more than those, who face these changes after a chain of transactions in both financial and goods markets occurs (Williamson, 2008). Similarly, Ledoit (2011) proves this effect using topological notions within a social network economy, where the most intensive trade occurs with the closest counterparties. As the central bank injects money into the financial system, liquidity permeates the whole economy, yet unevenly with a larger effect on entities, located closer to the "place of injection".

Income inequality might be further propagated through portfolio channel, proportionally to the share of nominal assets (typically, cash) possessed by the household. On assumption that poorer agents tend to hold higher money balances compared with richer ones, they become primary payers of the socalled inflation tax, as in Erosa and Ventura (2002). Additionally, limited substitutability between cash and other financial instruments expose them to the larger adverse impact of the expansionary monetary policy.

Yet, an unexpected inflationary pressure redistributes wealth not only from holders of nominal assets but also among them, provided some holders are borrowers while others - savers. Initially proposed in Fisher (1933), this wellknown impact of interest rate change has been quantified in the seminal paper of Doepke and Schneider (2006), assessing the potential impact of moderate inflation shock on wealth. Using the records on distribution and duration of nominal asset holdings in the U.S., it explicitly shows that inflation benefits young indebted households, generally representatives of the middle class, at the expense of the old and rich. Furthermore, prolonged episodes of inflationary pressure tend to have larger redistributive consequences for holders of long-term rather than short-term bonds, as they have a lower possibility to adjust to inflation. 
Although channels appear to be defined pretty well, two measurement issues arise on an attempt to quantify the corresponding effects: differentiating between correlation and causality and matching low-frequency data in the Survey of Consumer Finance or PSID to regular changes in the key policy rate. Both issues are addressed by the study of Coibion et al. (2017), based on quarterly Consumer Expenditure Survey, within the framework, separating surprise changes in monetary stance from forecast-driven ones. The analysis provides empirical evidence of a functioning income heterogeneity channel, having particularly disproportionate effect for rich households with a large share of financial proceeds. On the contrary, the impact of interest rate changes on labor income appears to be negligible, assigning a limited role to earnings heterogeneity channel.

The existence of empirical confirmation of the distribution channel has stimulated research in this field that remains largely overlooked from the policymaking perspective. A prominent example of the recent studies setting a theoretical background of monetary policy transmission is Auclert (2017). This paper unambiguously identifies three basic redistribution channels (earnings heterogeneity, Fisher (saving redistribution), and interest rate exposure channels) and claims that each of these mechanisms exacerbates the aggregate effects on consumption.

Kaplan et al. (2018) elaborate upon the study of Auclert (2017), incorporating heterogeneous agents, explicitly modeled production sector, uninsurable income shocks, and imperfect substitutability between liquid and illiquid assets. Yielding an empirically realistic joint distribution of income and wealth, the model attributes a pivotal impact of the expansionary monetary policy to labor demand shifts that drive consumption upward.

Luetticke (2017) employs a similar type of model to replicate empirical evidence. The study shows that consumption response is amplified by the contractionary shock while investment response - dampened, compared with the standard RANK model. This impact occurs as far as monetary policy differently affects households' portfolios and consumption decisions. Rich agents, holding primarily real assets, are able to stabilize investment and even increase demand for final goods due to a sizable income effect, dominating the substitution effect. Middle income and poor households, on the contrary, experience a sharp drop in consumption, partially offset by reducing holdings of liquid wealth. As in Kaplan et al. (2018), the direct transmission channel explains only $25 \%$ of the aggregate effect, pointing to significant flaws in standard RANK models, fully relying on the operations of this channel.

Still, the outlined HANK framework reproduces agents' earnings and wealth heterogeneity with respect to income status only, not age. The concept developed to approach the issue is an overlapping-generations model, which can include the required number of age cohorts. Although typically such models account for only two generations, limiting the scope of discussion to the young and the old in general, the paper of Heer and Maussner (2012) proposes dynamic optimizing sticky price model, where 240 cohorts of agents, heterogeneous with respect to the age and productivity, are present. Their study reveals that dynamics of aggregate variables are generally similar in both representative agent and overlapping generation models, yet not fully identical. The slight increase in a wedge between labor earnings of different cohorts in response to monetary shock is present. This effect, however, is largely tolerated through the means of taxation system, leading to an equalization of wealth distribution.

Thus, to quantify the redistributive effects of monetary policy in the life-cycle framework, the model of Heer and Maussner (2012) is adopted and adjusted to fit the purposes of research by dividing all households into 3 groups, depending on their attitudes to saving, similarly to Andres et al. (2018). Liquid assets in form of bonds are also introduced in the framework, calibrated to mimic wealth distribution and earnings processes across generations.

The present paper, however, is only a first step to develop a fully-fledged life-cycle model. There are a number of limitations, necessary to ensure a tractability of the model, which can potentially influence the result. First, the markets are complete, so that all households (except for exogenously defined hand-to-mouth households) can insure themselves against adverse income shocks and do not have an incentive to accumulate precautionary savings. Moreover, although the model includes both liquid and illiquid assets, agents have no choice among them; instead, patient agents are prescribed to accumulate illiquid assets while impatient - liquid ones. Thus, the captured Fisher effect is basically one-sided while portfolio effect is shown only in aggregated form. Additionally, the paper does not consider financial segmentation channel and unemployment effects on earnings heterogeneity at all.

\section{MODEL}

The model is a New-Keynesian DSGE model with overlapping generations, combining the features of Heer and Maussner (2012) and Andres et al. (2018). It consists of four basic sectors: households, firms, the government, and the central bank. Households solve the problem of lifetime utility maximization with regard to their intertemporal consumption, saving, and labor supply. Final goods producers operate in a competitive market, while intermediate goods producers maximize their profits in a monopolistically competitive environment and set prices in a staggered way a la Calvo (1983). The government sector is reduced to the pension fund, collecting social security taxes and providing retirees with pension benefits. The monetary authority controls the money supply, which grows at a constant rate. Aggregate firm productivity and monetary policy are stochastic.

\subsection{Households}

The lifespan of a household includes $T+T^{R}=60$ periods, lasting 1 year each. The first $T=42$ periods agents work and earn labor income while the remaining $T^{R}=18$ periods they are retired and receive pensions, which reflects average retirement age of 62 years in the U.S. and average lifetime on the retirement of 18 years (U.S. Office of Personnel Management, 2017). Each type of agent enters the model without wealth at age of 20 and leaves no bequests after dying at age of 80 .

The productivity of agents $e(s ; j ; h)$ depends on several factors: their type $j \in\{1,2,3\}$, corresponding to the individual's income status, namely poor, middle-class, and rich; wealth composition type, denoted by $h$; and cohort they belong to. Agents cannot switch their productivity type $j$ over the lifetime. The share of type- $j$ agents in each cohort is fixed at $\mu(j ; h)$. 
Household's type $h$ depends primarily on its attitude towards saving and, as a result, the structure of non-housing wealth. According to this criterion, households within each income group were subdivided into patient savers, impatient borrowers, and impatient hand-to-mouth consumers.

\subsubsection{Working households}

At time $t$, working patient household with productivity type $j$ holds capital $K_{t-1}$ from the previous period. It maximizes the expected life-time utility at age 1 in period $t$ with regard to consumption $C_{t}^{S ; j ; P}$, labor supply $N_{t}^{S ; j ; P}$, and nextperiod capital $K_{t+1}^{S+1 ; j ; P}$ :

$$
u\left(C_{t+S-1}^{S}, N_{t+s-1}^{S}\right)=E_{t} \sum_{s=1}^{T} \beta^{s-1}\left(\frac{\left(C_{t+s-1}^{S}\right)^{1-\sigma}-1}{1-\sigma}-\frac{\varphi_{0}\left(\left(N_{t+s-1}^{S}\right)^{1+\varphi}\right)}{1+\varphi}\right),
$$

subject to the real budget constraint

$$
\begin{gathered}
C_{t+s-1}^{s}+\left(K_{t+s-1}^{s+1}-(1-\delta) K_{t+s-2}^{s}\right)= \\
=\left(1-\tau_{t}^{s c}\right) W_{t+s-1} e(s ; j ; h) N_{t+s-1}^{s}+R_{t+s-1}^{k} K_{t+s-2}^{s}+D_{t+s-1},
\end{gathered}
$$

where expectations are based on the agent's information set as of period $t, \beta$ is a discount factor, and $\sigma>0$ stands for the parameter defining relative risk aversion. The worker earns income from the effective labor $e(s ; j ; h) N_{t+s-1}^{s}$ and return on capital $R_{t}^{k}$, pays social security tax $\tau_{t}^{s c}$, which is used to provide income for retirees, and receives profits $D_{t+s-1}$ in the form of dividends.

Impatient households maximize the same utility function, as patient households, but subject to a different budget constraint. As the mean of saving and borrowing they use liquid nominal bonds $B_{t-1}$, so that budget constraint in real terms is defined as

$$
\begin{gathered}
C_{t+s-1}^{s}+Q_{t+s-1} b_{t+s-1}^{s+1}= \\
=\left(1-\tau_{t}^{s c}\right) W_{t+s-1} e(s ; j ; h) N_{t+s-1}^{s}+\frac{b_{t+s-2}^{s}}{\pi_{t+s-1}}+D_{t+s-1},
\end{gathered}
$$

where $b_{t+s-2}^{s}$ denotes the real value of nominal debt, and $\pi_{t+s-1}$ stands for inflation rate.

Hand-to-mouth consumers, in line with Gali et al. (2007), fully consume their labor income and neither smooth their consumption with changes in labor income, nor substitute intertemporally with shifts in interest rates. Accordingly, their consumption is fully determined by the (real) budget constraint

$$
C_{t+s-1}^{s}=\left(1-\tau_{t}^{s c}\right) W_{t+s-1} e(s ; j ; h) N_{t+s-1}^{s} .
$$

The presence of such households, stemming typically from the lack of access to liquid financial markets or constantly binding borrowing constraints (in case of rich and poor households, respectively), and their impact on aggregate stabilization is outlined in Kaplan, Moll, and Violante (2018). As they do not face trade-offs between current and future consumption, the direct channel of monetary policy is ineffective to influence their behavior while indirect effects appear to be large.

\subsubsection{Retired households}

All patient and impatient retired household have labor supply $N_{t+s-1}^{s ; j h}=0$, so they maximize

$$
u\left(C_{t+s-1}^{S}\right)=E_{t} \sum_{s=T+1}^{T+T^{R}} \beta^{s-1}\left(\frac{\left(C_{t+s-1}^{S}\right)^{1-\sigma}-1}{1-\sigma}\right),
$$

subject to the real budget constraints

$$
\begin{aligned}
& C_{t+s-1}^{s}+\left(K_{t+s-1}^{s+1}-(1-\delta) K_{t+s-2}^{s}\right)= \\
& =P_{e n} n_{t+s-1}+R_{t+s-1}^{k} K_{t+s-2}^{s}+D_{t+s-1},
\end{aligned}
$$

for patient ones or

$$
C_{t+s-1}^{s}+Q_{t+s-1} b_{t+s-1}^{s+1}=P e n_{t+s-1}+\frac{b_{t+s-2}^{s}}{\pi_{t+s-1}}+D_{t+s-1}
$$

for impatient, where $P e n_{t+s-1}$ is a real pension income and is distributed lump-sum. The government sets pensions according to

$$
P e n_{t+s-1}=\zeta e(s ; j ; h) \bar{W}_{t} \bar{N}_{t},
$$

depending on the households' life-time productivity level, where $\bar{W}_{t}$ and $\bar{N}_{t}$ represent average wage and average labor supply of working cohorts, belonging to particular $j$ and $h$ types. The size of pension relative to income is defined by a parameter $\zeta$.

Consumption of hand-to-mouth retirees is financed solely by their state-provided pension, so that

$$
C_{t+s-1}^{s}=\operatorname{Pen}_{t+s-1} \text {. }
$$

\subsection{Producers}

The supply side of the economy is represented by two types of firms, which are final goods and intermediate goods producers. A continuum of perfectly competitive firms aggregates differentiated intermediate inputs distributed on $[0,1]$ according to a CES technology. The imperfect substitutability of the intermediates in the aggregation process causes a downward-sloping demand for each such input, allowing producers to set their own prices while treating all other prices as given. To replicate nominal rigidity in the economy, we use a staggered price setting a la Calvo (1983), so that each period only a random fraction of firms could reoptimize prices.

\subsubsection{Final good firms}

These firms aggregate a continuum of intermediate goods $Y_{t}(i)$ distributed on $[0,1]$ into a homogenous consumption good using the constant elasticity of substitution technology

$$
Y_{t}=\left(\int_{0}^{1} Y_{t}(i)^{\frac{\epsilon-1}{\epsilon}} d i\right)^{\frac{\epsilon}{\epsilon-1}},
$$

where the price elasticity of demand $\epsilon>1$. Under assumption of perfect competition, final goods producer solves the profit maximization problem, which solution defines the relative demand function for the $i^{\text {th }}$ intermediate good

$$
Y_{t}(i)=\left(\frac{P_{t}(i)}{P_{t}}\right)^{-\epsilon} Y_{t}
$$

where $P_{t}(i)$ and $P_{t}$ stand for the price of good $\mathrm{i}$ and the average level of prices, respectively. Then, aggregate price level is

$$
P_{t}=\left(\int_{0}^{1} P_{t}(i)^{1-\epsilon} d i\right)^{\frac{1}{1-\epsilon}}
$$




\subsubsection{Intermediate good firms}

A representative intermediate firm indexed by $i \in[0,1]$ produces output $Y_{t}(i)$ according to a Cobb-Douglas CRS technology using capital $K_{t-1}(i)$ and effective labor $N_{t}(i)$ according to

$$
Y_{t}(i)=A_{t} K_{t-1}(i)^{\alpha} N_{t}(i)^{1-\alpha},
$$

where $A_{t}$ is a common productivity shock, following $\mathrm{AR}(1)$ process

$$
\ln A_{t}=\rho_{a} \ln A_{t-1}+\varepsilon_{a t},
$$

where $\varepsilon_{a t}$ is i.i.d., $\varepsilon_{a t} \sim N\left(0, \sigma_{a}^{2}\right)$.

The optimization problem of each intermediate goods producer consists of two stages. At the first stage, the firm minimizes its real cost of renting $K_{t-1}(i)$ and $N_{t}(i)$ in perfectly competitive factor markets at price $r_{t}$ and $W_{t}$, respectively:

$$
\min _{N_{t}(i), K_{t-1}(i)} r_{t} K_{t-1}(i)+\left(1+\tau_{t}^{s c} W_{t} N_{t}(i),\right.
$$

subject to

$$
Y_{t}(i)=A_{t} K_{t-1}(i)^{\alpha} N_{t}(i)^{1-\alpha},
$$

in order to determine optimal input quantities.

At the second stage, intermediate goods producers solve the problem of discounted real profit maximization by setting the price. The presence of market power allows modeling nominal price rigidity, following Calvo (1983). Each firm is able to change its price with a constant probability 1- $\theta$ and maintains the price set previously with probability $\theta$ in a given period. Hence, the producer accounts for the possibility of being stuck with today's price several periods ahead in solving profit maximization problem. The reoptimizing firm solves

$$
\max _{P_{t}(i)} E_{t} \sum_{k=0}^{\infty}(\beta \theta)^{k} \frac{\lambda_{t+k}}{\lambda_{t}}\left\{\left(\frac{P_{t}(i)}{P_{t+k}}-M C_{t+k}\right) Y_{t+k}(i)\right\},
$$

subject to its demand function

$$
Y_{t}(i)=\left(\frac{P_{t}(i)}{P_{t}}\right)^{-\epsilon} Y_{t}
$$

where $\frac{\lambda_{t+k}}{\lambda_{t}}$ represent stochastic discount factor, which is the multiplier on the nominal budget constraint of household in a $t+k$ period. Since the households hold ownership rights on the intermediate good firms and receive the firm profits, the firms weigh future profits using the factor, incorporating demand. that

Under a symmetric equilibrium, optimal price $P_{t}^{*}(i)=P_{t}^{*}$ so

$$
\begin{gathered}
\frac{P_{t}^{*}(i)}{P_{t}}=\frac{P_{t}^{*}}{P_{t}}= \\
=\frac{\epsilon}{\epsilon-1} \frac{E_{t} \sum_{k=0}^{\infty}(\beta \theta)^{k} \lambda_{t+k}\left(\prod_{s=1}^{k} \pi_{t+s}\right)^{\epsilon} M C_{t+k} Y_{t+k}}{E_{t} \sum_{k=0}^{\infty}(\beta \theta)^{k} \lambda_{t+k}\left(\prod_{s=1}^{k} \pi_{t+s}\right)^{\epsilon-1} Y_{t+k}} .
\end{gathered}
$$

Given Calvo's pricing, the aggregate price level in the period tcan be calculated as follows

$$
P_{t}^{1-\epsilon}=\int_{0}^{1} P_{t}(i)^{1-\epsilon} d i=\theta P_{t-1}^{1-\epsilon}+(1-\theta) P_{t}^{* 1-\epsilon},
$$

where the price $P_{t}^{*}$ is set by a fraction of producers (1- $\left.\theta\right)$ who are able to choose the optimal price in that period, and a fraction $\theta$ holds the price $P_{t-1}$ from the previous period. Dividing by $P_{t}^{1-\epsilon}$,

$$
1=\theta\left(\frac{1}{\pi_{t}}\right)^{1-\epsilon}+(1-\theta)\left(\pi_{t}^{*}\right)^{1-\epsilon},
$$

where $\pi_{t}^{*}=\frac{P_{t}^{*}}{P_{t}}$.

\subsection{Monetary authority}

The central bank controls the money supply following the money growth rule

$$
g_{m}=\ln \left(\frac{M_{t}}{M_{t-1}}\right)
$$

where $M_{t}$ is the nominal stock of money, which grows at rate $g_{m}$. The growth rate $g_{m}$ is subject to exogenous shock i.i.d. $\varepsilon_{m, \nu^{\prime}} \varepsilon_{m, t} \sim$ $N\left(0, \sigma_{m}^{2}\right)$, and follows $A R(1)$ process of the form

$$
g_{m, t}=\rho_{m} g_{m, t-1}+\varepsilon_{m, t} .
$$

A positive (negative) realization of $\varepsilon_{m, t}$ should be interpreted as a expansionary (contractionary) monetary policy shock, leading to a decline (rise) in the nominal interest rate, given inflation, and the output gap.

\subsection{Government}

The government uses the revenues from taxing labor in order to finance its expenditures on social security

$$
\tau_{t}^{S C} W_{t} N_{t}-\frac{T^{R}}{T+T^{R}} \sum_{h=1}^{3} \sum_{j=1}^{3} \sum_{s=T+1}^{T+T^{R}} P e n_{t}=P F_{t},
$$

where $P F_{t}$ is a balance of pension fund. Pensions are set according to the rule, specified by

$$
P e n_{t+s-1}=\zeta e(s ; j ; h) \bar{W}_{t} \bar{N}_{t},
$$

where $\zeta$ is a predetermined replacement ratio of pension income with respect to average wage earnings for each type of household.

\subsection{Aggregation}

Aggregate and individual behaviors are consistent, i.e. the sum of the individual consumption, labor supply, and capital and bond holdings is equal to the aggregate level of consumption, labor supply, and capital and bond holdings, respectively

$$
\begin{gathered}
C_{t}=\sum_{h=1}^{3} \sum_{j=1}^{3} \sum_{s=1}^{T+T^{R}} C_{t}^{S ; j ; h} \frac{\mu(j)}{T+T^{R}} \\
N_{t}=\sum_{h=1}^{3} \sum_{j=1}^{3} \sum_{s=1}^{T} N_{t}^{s ; j ; h} \frac{\mu(j)}{T} \\
K_{t}=\sum_{j=1}^{3} \sum_{S=1}^{T+T^{R}} K_{t}^{S ; j ; P} \frac{\mu(j)}{T+T^{R}} \\
B_{t}=\sum_{j=1}^{3} \sum_{s=1}^{T+T^{R}} B_{t}^{s ; j ; I} \frac{\mu(j)}{T+T^{R}} .
\end{gathered}
$$


Under Calvo's pricing, expression for aggregate demand is transformed from the standard

$$
Y_{t}=C_{t}+I^{\prime}
$$

into

$$
\frac{A_{t} K_{t-1}^{\alpha} N_{t}^{1-\alpha}}{v_{t}^{p}}=\left(C_{t}+I_{t}\right)
$$

where

$$
v_{t}^{p}=\int_{0}^{1}\left(\frac{P_{t}(i)}{P_{t}}\right)^{-\epsilon} d i=\theta\left(\frac{1}{\pi_{t}}\right)^{-\epsilon} v_{t-1}^{p}+(1-\theta)\left(\pi_{t}^{*}\right)^{-\epsilon} .
$$

The model is closed by demand for real money balances

$$
M_{t}^{\text {real }}=\frac{Y_{t}}{\left(\frac{1}{Q_{t}}-1\right)^{\eta}} .
$$

\section{CALIBRATION}

There is a set of objectives that should be achieved in calibrating the model. Primarily, the simulated distribution of positive and negative wealth should correspond to the actual one, observed in the data. Additionally, stochastic productivity factor should replicate the earnings patterns for each specific type of household. The rest of parameters are set to values, which are commonly accepted in the New Keynesian literature.

\subsection{Wealth distribution}

Calibration of household wealth relies primarily on the classification of households according to their income group and asset structure. Following Andres et al. (2018), the paper employs PSID data for the year 2015 to assign each household to patient/impatient categories based on their holdings of liquid and illiquid non-housing wealth, as well as a size of this wealth relative to their income. Although mortgages occupy a notable portion of agents' balance sheets, investment in housing, signaling a high rate of time discounting (delivers utility immediately), is not considered. The identification strategy is summarized in Table 1 below. For the rest of the paper, a $50 \%$-threshold is applied.

Next, using the percentiles of income distribution as of 2015 , the households are assigned the status of poor, middle-income, and rich if they belong to bottom 25th percentile, from 25 th to 75 th percentile, and the top 25th percentile, respectively. The relative weights of each household type by income group consequently correspond to the $25 \%$ for top and bottom quantiles and $50 \%$ for the middle class.

Table 2 recapitulates the aggregate shares of households in the data, derived by multiplying shares of patient and impatient households on their wealth percentiles. However, as the model contains 60 cohorts of agents within each classified group, parameters $\mu(j ; h ; s)$ take into account shares of each age group within outlined relative weights.

The calibrated model generally matches the distribution of wealth across generations (Figure A1 and A2 in Appen$\operatorname{dix}$ A). There are, however, several drawbacks, associated primarily with the model logic. As agents are born without capital and leave no bequests, the simulated distribution of wealth of poor patient households in earlier and later years of their lifetime is below the levels observed in real data. On the contrary, asset holdings of the rich are overestimated for the retired individuals, which might occur due to a rather small number of observations for this group.

For impatient households, who mainly borrow in liquid bonds, because of embedded prudency requirements (agents cannot default on their debts), mismatch between observed and simulated wealth is more pronounced. Within the model framework, income dynamics of the poor impatient households deters them from rapid debt accumulation during their early years. Accordingly, reduction in income of middle class at retirement reduces their borrowings.

Table 1. PSID sample weights for year 2015, in \%

\begin{tabular}{lcccc}
\hline & Threshold & $\mathbf{a}=\mathbf{2 5 \%}$ & $\mathbf{a}=\mathbf{5 0 \%}$ & $\mathbf{a}=\mathbf{7 5 \%}$ \\
\hline Patient (P) & $W \geq a \cdot I$ & 45.5 & 33.4 & 27.0 \\
Impatient (HTM) & $0<W<a \cdot I$ & 32.2 & 44.3 & 50.7 \\
Impatient (I) & $W \leq 0$ & 22.3 & 22.3 & 22.3 \\
\hline
\end{tabular}

Table 2. Relative weights of households in the population, in $\%$

\begin{tabular}{lccc}
\hline & p0 - p25 & p26 - p74 & p75 - p100 \\
\hline Patient (P) & 12.6 & 16.7 & 5.0 \\
Impatient (HTM) & 9.0 & 28.4 & 6.6 \\
Impatient (I) & 5.3 & 9.2 & 7.3 \\
\hline
\end{tabular}




\subsection{Earnings dynamics}

Provided that wage, determined by the cost-minimization problem of intermediate producers, is identical for all agents, the idiosyncratic productivity becomes a key factor, driving heterogeneity in labor income across households. Hence, the productivity is calibrated in a way, related to the literature on earnings processes rather than any human capital accumulation theories. The traditional approach to evaluate income dynamics, originating from the work of Friedman and Kuznets (1954), involves a decomposition of shocks into permanent and transitory components. The simplest model takes the form

$$
y_{i, t}=\alpha_{i}+v_{i, t^{\prime}}
$$

where $\alpha_{i}$ represents the individual time-invariable element with variance $\sigma_{\alpha}^{2}$ and $v_{i, t}$ is independently identically distributed and serially uncorrelated temporary shock with variance $\sigma_{v}^{2}$. By assumption, $\operatorname{cov}\left(\alpha_{i}, v_{i, t}\right)=0$.

The productivity is calibrated using data on total labor income of households head from the PSID for 2001-2015 years, containing surveys of a representative sample of U.S. households every odd year. Due to the specificity of a dataset, each individual is characterized by 8 consecutive observations with a break every second year; moreover, there is no person with a full earnings profile, covering required 42 years. Therefore, before the estimation of general permanent-transitory models, time and age factors are extracted from deflated (log) labor income, $y_{i, t}$,

$$
y_{i, t}=\beta_{0}+\beta_{1} \text { age }_{i, t}+\beta_{2} \text { time }+\varepsilon_{i, t} .
$$

The residuals $\varepsilon_{i, t}$, representing average labor earnings along the individuals' lifecycle, are then disentangled into components according to the following set of equations (Doris et al., 2011):

$$
\begin{gathered}
\varepsilon_{i, t}=p_{t}\left(\alpha_{i}+\omega_{i, t}\right)+\lambda_{t} v_{i, t^{t}} \\
\omega_{i, t}=\omega_{i, t-1,}
\end{gathered}
$$

where $p_{t}$ and $\lambda_{t}$ are parameters, capturing a common pattern of changes in the permanent and transitory components across agents.

Given an insufficient number of observations with nonzero values for work experience, required to characterize the changes in permanent component of income in the data, $\omega_{i, t}$ is assumed to be persistent across time. Transitory shocks follow an ARMA(1,1) process, with AR parameter $\rho$ and MA parameter $\gamma$ :

$$
v_{i, t}=\rho v_{i, t-1}+\gamma \epsilon_{i, t-1}+\epsilon_{i, t^{\prime}}
$$

where $\epsilon_{i, t}$ is a random variable, $\epsilon_{i, t} \sim N\left(0, \sigma_{\epsilon}^{2}\right)$.

The model parameters, estimated in Stata, using generalized method of moments for a household of each type and income group separately, serve as inputs to the Matlab program, generating idiosyncratic productivity paths (Figure A3 in Appendix A).

The resulting productivity profiles are suitable to replicate salient features of wealth distribution. However, as financial markets are complete, simulated deviations from the general trend have no considerable impact on wealth dynamics and can be easily insured against.

\subsection{Remaining model parameters}

The rest of the OLG model is calibrated in line with other New-Keynesian literature, reflecting basic characteristics of the U.S. post-war economy (Table 3). Since the periods in model correspond to years instead of quarters, some conventional parameter values are taken to the power of 4 .

Following lacoviello (2005), discount factors for the patient and impatient households, reflecting annual timespan, are $0.99^{4}=0.9606$ and $0.95^{4}=0.8145$, respectively. The parameter $\sigma$ is equal to the conventional value of 2.0. The previous studies on labor market specify a conservative value of 0.3 for the Frisch labor supply elasticity that corresponds to $\varphi=7.0$. Social security tax $\tau^{s c}$ is set to 0.1530 .

Table 3. Calibrated parameter values

\begin{tabular}{lcc}
\hline Parameter name & Notation & Value \\
\hline Discount factor (patient households) & $\beta_{P}$ & 0.961 \\
Discount factor (impatient households) & $\beta_{I}$ & 0.815 \\
Relative risk aversion coefficient & $\sigma$ & 2.000 \\
Frisch labor supply elasticity & $\varphi$ & 7.000 \\
Relative disutility from labor & $\varphi_{o}$ & 0.260 \\
Social security tax rate & $\tau^{s c}$ & 0.153 \\
Capital share & $\alpha$ & 0.360 \\
Depreciation & $\delta$ & 0.076 \\
Calvo parameter & $\theta$ & 0.202 \\
Elasticity of substitution & $\epsilon$ & 6.000 \\
\hline
\end{tabular}


The growth of nominal money supply is an $A R(1)$ process with a standard autocorrelation parameter $\rho_{m}=0.5$ (Heer and Maussner, 2012). In steady state, both inflation and money growth are set to zero.

The capital's share of income $\alpha$ is calibrated to 0.36 and the yearly depreciation rate $\delta$ is $0.019 * 4=0.076$. The nominal rigidity is modeled under the assumption that each quarter producers are unable to adjust their prices with the probability 0.67 . It implies that yearly Calvo parameter $\theta$ is equal to 0.2015 . Total supply chain markup considered to be about $20.0 \%$ so the markup in the model $\frac{1}{M C_{t}}$ is equal to 1.2 which corresponds to the elasticity of substitution between intermediate products $\epsilon=6.0$. Technology follows an $A R(1)$ process with parameter $\rho_{a}$ set to a conventional value of 0.95

\section{REDISTRIBUTIVE EFFECTS OF MONETARY POLICY}

The results and implications of expansionary monetary shock are presented in two blocks. First, the impact on the aggregate economy and household sector, split along income quantiles, is discussed and compared with the previous findings. Next, heterogeneity in responses for each population segment is examined along theoretical underpinnings on distributive transmission channels. The results of model simulation point to a widening intergenerational inequality gap, which is a consequence of simultaneous impact all considered channels except one.

\subsection{Aggregate responses}

On the impact of 5 percentage point unanticipated increase in yearly inflation (Figure A4 in Appendix A), initial response of output is slightly negative, as some firms cannot adjust their prices while marginal costs scale up (an immediate hike in real wage is accompanied by protracted decrease in return on capital). The equilibrium employment falls as a result of both substitution effect on the demand side of the labor market (producers substitute labor by relatively cheaper capital) and income effect on the supply side. Provided that labor earnings increase, consumption is affected positively.

As investment becomes less expensive, patient agents in all income percentiles respond by increasing capital stock (Table 4); the dynamics of capital accumulation creates the major difference between them. Whereas the largest share of total wealth gain is attributed to the rich, inequality among patient households widens slightly.

An emerging inflationary pressure benefits impatient households, who are net borrowers, by decreasing their stock of debts borne from previous periods, as in Doepke and Schneider (2006). Although it makes real disposable income higher, current borrowing decline disproportionately across income groups because of the high substitution effect. However, as savers among holders of liquid assets are virtually absent, the way transmission occurs between borrowers can only partially comparable with the Fisher channel, traditionally transferring wealth from savers to borrowers.

Income and earnings heterogeneity channels exhibit additional impact on the aggregate model dynamics. Table 5 shows the split of gains and losses for each part of the households' budget constraints, depending on their income quantile.

Provided that the model does not consider unemployment and staggered wage setting (typically regarded as the main driving forces of increase in labor earnings of the poor), growing wage becomes the key impetus for labor earnings. In line with previous empirical findings, agents in top 25th percentile benefit the most from loose financial conditions. These factors combined, inequality tends to increase, as the magnification of hourly wages is larger than the decline in unemployment (equal to zero here).

The inflationary episode, leading to a decline in both real returns on capital and real interest on bonds, have fairly

\section{Table 4. Wealth gains/losses arising from an unexpected increase in money supply, by income group, in \%}

\begin{tabular}{lcc}
\hline Households & Illiquid wealth & Liquid wealth \\
\hline Poor & 4.309 & -0.424 \\
Middle-income & 4.861 & -0.105 \\
Rich & 5.060 & -0.818 \\
\hline
\end{tabular}

\section{Table 5. Income gains/losses arising from an unexpected increase in money supply, by income group, in \%}

\begin{tabular}{lcccc}
\hline Households & Labor income & $\begin{array}{c}\text { Real return } \\
\text { on capital }\end{array}$ & $\begin{array}{c}\text { Real interest } \\
\text { on bonds }\end{array}$ & Real pension \\
\hline Poor & 0.075 & 0.021 & -9.388 & -0.421 \\
Middle-income & 0.105 & 0.064 & -7.053 & -0.265 \\
Rich & 0.163 & 0.074 & -8.560 & -0.236 \\
\hline
\end{tabular}


similar implications for consumption of patient and impatient households in spite of the essential difference in the modalities of operation. Illiquid wealth accumulation, driven up by lower cost of investment, is strong enough to offset the reduction of the rate of return, so that total financial income increase. Disproportionality of this increase is primarily driven by the difference in total capital stock, distribution of which is skewed to the right. In the meantime, bondholders with short positions face a lower implicit cost of borrowing across periods. In other words, they have to pay lower interest to get next-period bond, and hence, have more disposable income.

Transfers from the government, represented here by pensions, have a countercyclical nature, and hence, shrink on the impact of $5 \%$ inflation shock. The change is relatively higher for low-income households, as retirement income, which depends on both contemporary and past earnings dynamics, respond more to a decline in average work hours.

Generally, income heterogeneity channel, in line with theoretical notions, contributes to inequality in so far real returns on illiquid assets of the rich agents are exposed to stronger positive effect while transfers - smaller negative, in comparison with those of individuals in the bottom 25th percentile of the income distribution. Thus, all 4 out of 5 theoretical transmission channels (financial segmentation is dropped from consideration because of model limitations) contribute to an increase in inequality among households, belonging to different income quantiles, after a positive money supply shock. Although this partially contrasts with the evidence, such result can be attributed primarily to the particular setting of the model, which allows only for onesided Fisher and earnings heterogeneity channels.

\subsection{Individual responses}

The aggregate responses, however, mask notable discrepancies in reactions of agents of different age. To the extent asset holdings, labor earnings, and interest income (or expense) vary across generations, the observed impact of transmission channels is likely to be augmented.
Among poor patient households (Table 6), two sets of cohorts benefit the most from expansionary policy shock: of pre-retirement age (57 - 62 years), who hold the highest capital stock on expectation of a drop in income after the retirement, and agents from 27 to 32 years old, facing a temporary reduction in productivity (Appendix A, Figure A3). The difference in illiquid wealth gains of working-age generations is, however, relatively insignificant, so the observed distributional effects are small.

On the contrary, the benefit of retirees is lower and diminishes with age. In essence, this dynamics is primarily influenced by the gradual reduction of capital stock held by the elderly, as they do not leave bequests to their offspring.

Disproportionality in changes of bond holdings is driven by a varying exposure of agents to income and substitution effects. As higher inflation reduces the real value of debt, held from the previous period, households have higher disposable income; furthermore, the intensity of such impact depends on the total amount of negative wealth: high debts devaluate by more. Hence, middle-age cohorts receive relatively larger upsurge in disposable income after inflationary episode than younger or older agents.

Additionally, increase in labor income, which constitutes a considerable share of the household budget, varies across age groups, benefitting individuals of pre-retirement age to a greater extent (discussed in details further; see Table 9). Compared with younger workers and retirees, these cohorts get the highest addition to disposable income, so income effect dominates the substitution, and they increase both consumption and debt.

In contrast, provided that price of bonds turn out to be higher as yield drops, agents to 38 years and above 63 years old, who experience both a minor decrease in the value of previous debts and get lower increase in labor earnings (pensions even cut on inflation hike), tend to consume more while borrowing less.

Table 6. Wealth gains/losses of poor households arising from an unexpected increase in money supply, by age, in \%

\section{Poor households}

\begin{tabular}{ll}
\hline $21-26$ years & 4.00 \\
$27-32$ years & 4.75 \\
$33-38$ years & 4.73 \\
$39-44$ years & 4.69 \\
$45-50$ years & 4.64 \\
$51-56$ years & 4.638 \\
$57-62$ years & 4.759 \\
$63-68$ years & 4.31 \\
$69-74$ years & 3.831 \\
$75-80$ years & 2.34 \\
\hline
\end{tabular}

Liquid wealth

$-1.048$

$-0.739$

$-0.279$

0.239

0.777

1.050

0.525

$-2.427$

$-1.889$

$-0.612$ 


\section{Table 7. Wealth gains/losses of middle-income households arising from an unexpected increase in money supply, by age, in \%}

\begin{tabular}{lcc}
\hline $\begin{array}{l}\text { Middle-income } \\
\text { households }\end{array}$ & Illiquid wealth & Liquid wealth \\
\hline $21-26$ years & 4.624 & -1.098 \\
$27-32$ years & 4.849 & -0.690 \\
$33-38$ years & 4.916 & -0.150 \\
$39-44$ years & 5.001 & 0.415 \\
$45-50$ years & 5.100 & 0.931 \\
$51-56$ years & 5.248 & 1.314 \\
$57-62$ years & 5.465 & 1.123 \\
$63-68$ years & 4.965 & -1.110 \\
$69-74$ years & 4.317 & -1.127 \\
$75-80$ years & 2.508 & -0.634 \\
\hline
\end{tabular}

The pattern, outlined for the poor, equally applies to the middle class (Table 7); the difference primarily lies in the size of positive effects both on capital holdings and current-period debt accumulation by cohorts from 39 to 62 years.

Although the dynamics of capital accumulation in the life-cycle framework is as well repeated for rich households (Table 8), due to relatively lower gain from debt devaluation, they are less inclined to extend borrowing for the future. Thus, only two cohorts of middle age tend to marginally increase short positions in bonds.

Therefore, monetary policy tends to exhibit similar impact on wealth distribution across generations, regardless of the type of assets, dominating households' portfolios (yet, this is not purely a portfolio channel, which presupposes the pres- ence of money balances as a form of liquid wealth). Provided that within each income group generations of pre-retirement age, already holding the largest share of capital, tend to benefit the most, inequality among patient households widens. Additionally, as agents of 39-62 years can increase borrowing to finance future consumption, contrary to younger and older individuals, impatient households are also exposed to growing intergenerational inequality.

Turning to the analysis of earnings heterogeneity channel, a specific pattern can be observed for households belonging to all three income groups (Table 9, Table 10, and Table 11): though the wage grows substantially, agents from 21 to 44 years old get only slight increase in labor income while older (and more productive) workers receive generally three to five times more.

Table 8. Wealth gains/losses of rich households arising from an unexpected increase in money supply, by age, in \%

\begin{tabular}{lcc}
\hline Rich households & Illiquid wealth & Liquid wealth \\
\hline $21-26$ years & 4.717 & -1.557 \\
$27-32$ years & 4.787 & -1.222 \\
$33-38$ years & 4.860 & -0.803 \\
$39-44$ years & 4.955 & -0.323 \\
$45-50$ years & 5.084 & 0.009 \\
$51-56$ years & 5.274 & 0.117 \\
$57-62$ years & 5.550 & -0.623 \\
$63-68$ years & 5.047 & -4.779 \\
$69-74$ years & 4.378 & -4.797 \\
$75-80$ years & 2.578 & -2.461 \\
\hline
\end{tabular}


Table 9. Income gains/losses of poor households arising from an unexpected increase in money supply, by age, in \%

\begin{tabular}{lccc}
\hline Poor households & Labor income & Real return on capital & Real interest on bonds \\
\hline $21-26$ years & 0.022 & 0.004 & -19.591 \\
$27-32$ years & 0.022 & 0.012 & -9.375 \\
$33-38$ years & 0.028 & 0.021 & -6.335 \\
$39-44$ years & 0.025 & 0.027 & -5.092 \\
$45-50$ years & 0.151 & 0.031 & -4.368 \\
$51-56$ years & 0.138 & 0.033 & -3.915 \\
$57-62$ years & 0.256 & 0.031 & -3.086 \\
$63-68$ years & & 0.027 & -1.748 \\
$69-74$ years & & 0.023 & -2.045 \\
$75-80$ years & & 0.011 & -4.371 \\
\hline
\end{tabular}

The disproportionality is an outcome of interaction of several factors: productivity, which determines the labor income for each cohort and income percentile, increases from earlier to later years of working life, and thus, magnifies any positive effect on homogeneous wage; minor decline in labor hours of hand-to-mouth households, whose decisions are not influenced by the change in interest rate due to absence of intertemporal optimization; shares of patient and hand-to-mouth agents increase with age in the data while of impatient - falls. Without effect from unemployment reduction, earnings heterogeneity channel increases inequality not solely between the poor and the rich, but among older and younger workers (who could potentially benefit more if unemployment dynamics has been taken into account).
The real return on capital augments across cohorts for all income groups proportionately to the positive response of their asset holdings. Hence, the largest benefits are acquired by the agents of pre-retirement age while the youngest individuals obtain the lowest percentage increase in this type of income.

On the contrary, a decline in the real interest on bonds as a result of monetary policy shock is the most notable for agents from 21 to 32 years old, which is likely to be the outcome of both lower interest rate and debt deflation. The absolute value of decline diminishes with age, leading to an equalization of income distribution, initially impaired by the dynamics of capital returns.

\section{Table 10. Income gains/losses of middle-income households arising from an unexpected increase in money supply, by age, in \%}

\begin{tabular}{lccc}
\hline $\begin{array}{l}\text { Middle-income } \\
\text { households }\end{array}$ & Labor income & Real return on capital & Real interest on bonds \\
\hline $21-26$ years & 0.113 & 0.008 & -16.712 \\
$27-32$ years & 0.007 & 0.021 & -8.426 \\
$33-38$ years & -0.003 & 0.035 & -5.906 \\
$39-44$ years & 0.056 & 0.051 & -4.857 \\
$45-50$ years & 0.139 & 0.065 & -4.305 \\
$51-56$ years & 0.249 & 0.081 & -3.879 \\
$57-62$ years & 0.296 & 0.096 & -3.872 \\
$63-68$ years & & 0.097 & 0.024 \\
$69-74$ years & & 0.073 & 0.086 \\
$75-80$ years & & 0.032 & -1.142 \\
\hline
\end{tabular}




\section{Table 11. Income gains/losses of rich households arising from an unexpected increase in money supply, by age, in \%}

\begin{tabular}{lccc} 
Rich households & Labor income & Real return on capital & Real interest on bonds \\
\hline $21-26$ years & -0.023 & 0.007 & -23.757 \\
$27-32$ years & 0.003 & 0.022 & -12.364 \\
$33-38$ years & 0.089 & 0.035 & -8.136 \\
$39-44$ years & 0.087 & 0.050 & -6.342 \\
$45-50$ years & 0.247 & 0.067 & -5.622 \\
$51-56$ years & 0.262 & 0.085 & -5.535 \\
$57-62$ years & 0.407 & 0.105 & -4.154 \\
$63-68$ years & & 0.109 & -2.093 \\
$69-74$ years & & 0.082 & -2.227 \\
$75-80$ years & & 0.037 & -3.097 \\
\hline
\end{tabular}

\section{CONCLUSIONS}

The use of unconventional tools to conduct monetary policy has increased the attention of the public and, consequently, policymakers to the redistributive effect they entail. However, the primary issue that still remains to be extensively scrutinized is the impact of traditional interest rate changes on the distribution of income and wealth. While researchers are increasingly engaged in incorporating heterogeneous agents into otherwise standard New-Keynesian models to replicate the salient features of wealth and earnings dynamics across households, belonging to different income percentiles, and the impact of the central bank's actions, monetary transmission mechanism in the life-cycle framework remain relatively unstudied.

The present paper is an attempt to take some first steps in filling this gap by employing a heterogeneous agent NewKeynesian model with overlapping generations to study the redistributive effects caused by an expansionary monetary policy. It mimics the observed distribution of wealth and earnings dynamics across households, clustered according to their income percentile and attitude to saving. By explicitly defining 60 cohorts, equal to 60 years of agents' lives, the model provides a convenient tool to disentangle the responses of aggregate variables into a spectrum of individual reactions to changes in policy stance. However, as of now, it accounts only for a limited number of transmission channels.

Generally, the findings reveal that an expansionary monetary shock tends to increase inequality among generations by benefitting agents of middle and pre-retirement age the most. Emerging inflationary pressure deflates their debts, held from previous periods, to a higher extent than for any other cohort, leading to a notable increase in their real disposable income. This triggers a strong positive response in both current and future consumption, financed through additional borrowing. Holders of illiquid wealth aged 51 to 62 years build up the highest additional capital stock as real interest rate falls, making investment cheaper. Although the overall dynamics cannot be attributed to a particular channel of monetary transmission because of the model's limitations, separately the effects are in line with one-sided portfolio and Fisher channels.

A disproportional increase in labor income also tends to contribute to growing inequality. Provided that the model does not account for a reduction in unemployment, wages become the key driving force of earnings dynamics. In so far that older (and more productive workers) get a higher increase in their salaries, the gap between generations widens. The divergence of this result from a traditional understanding of the earnings heterogeneity channel is primarily explained by the absence of employment consequences and an immediate response of wages (in contrast to staggered wage adjustment, benefitting the poor and the young).

Financial income differences work in opposite directions for patient and impatient households. While the former observe a proportional increase in their real return on capital relative to illiquid asset holdings, the latter pay lower real interest on their bonds, and the magnitude of this reduction in interest payments falls (in absolute terms) from younger to older agents, smoothing differences in total income.

However, a fully-fledged life-cycle framework would require a better reflection of traditional monetary transmission channels. Moreover, the analysis could be further enriched by quantifying the MPC of every cohort and household type exhibiting a substantial impact on aggregate stabilization, and by adding mortgage debts, which make up a substantial part of a household's assets. 


\section{REFERENCES}

Andrés J., Bosca J.E., Ferri J., Fuentes-Albero C. (2018). Household's Balance Sheets and the Effect of Fiscal Policy. Finance and Economics Discussion Series 2018-012. Washington: Board of Governors of the Federal Reserve System. Available at https://www.federalreserve.gov/ econres/feds/files/2018012pap.pdf

Ando A., Modigliani F. (1963). The "Life Cycle" Hypothesis of Saving: Aggregate Implications and Tests. American Economic Review, Vol. 53, No. 1, Part 1 (Mar., 1963), pp. 55-84. Available at https://www.jstor.org/stable/1817129

Auclert A. (2017). Monetary Policy and the Redistribution Channel. NBER Working Papers, No. 23451, National Bureau of Economic Research, Inc. Available at https://www.nber. org/papers/w23451.pdf

- Bernanke B. S., Gertler M. (1995). Inside the Black Box: The Credit Channel of Monetary Policy Transmission. Journal of Economic Perspectives, Vol. 9, No. 4, pp. 27-48. https://doi. org/10.1257/jep.9.4.27

Calvo G. A. (1983). Staggered Prices in a Utilitymaximizing Framework. Journal of Monetary Economics, Vol. 12, No. 3, pp. 383-398. https://doi.org/10.1016/03043932(83)90060-0

- Coibion O., Gorodnichenko Y., Kueng L., Silvia J. (2017). Innocent Bystanders? Monetary Policy and Inequality. Journal of Monetary Economics, Vol. 88, No. C, pp. 70-89. https://doi. org/10.1016/j.jmoneco.2017.05.005

- Constancio V. (2017). Inequality and Macroeconomic Policies. Intervention, the Annual Congress of the European Economic Association, Lisbon, August 22, 2017. Available at https://www.ecb.europa.eu/press/key/date/2017/html/ecb. sp170822.en.html

Doepke M., Schneider M. (2006). Inflation and the Redistribution of Nominal Wealth. Journal of Political Economy, Vol. 114, No. 6, pp. 1069-097. https://doi.org/10.1086/508379

- Doris A., O’Neill D., Sweetman O. (2011). GMM Estimation of the Covariance Structure of Longitudinal Data on Earnings. Stata Journal, Vol. 11, No. 3, pp. 439-459.

Erosa A., Ventura G. (2002). On Inflation as a Regressive Consumption Tax. Journal of Monetary Economics, Vol. 49, No. 4, pp. 761-795. https://doi.org/10.1016/S03043932(02)00115-0

- Fisher I. (1933). The Debt-Deflation Theory of Great Depressions. Econometrica, Vol. 1, No. 4, pp. 337-357.

- Fleming J. M. (1962). Domestic Financial Policies under Fixed and under Floating Exchange Rates. IMF Staff Papers, Vol. 9, No. 3, pp. 369-380.

Friedman M., Kuznets S. (1954). Income from Independent Professional Practice. National Bureau of Economic Research, Inc.

• Galí J., López-Salido J. D, Vallés J. (2007). Understanding the Effects of Government Spending on Consumption. Journal of the European Economic Association, Vol. 5, No. 1, pp. 227-270. https://doi.org/10.1162/JEEA.2007.5.1.227

Gornemann N., Kuester K, Nakajima M. (2012). Monetary Policy with Heterogeneous Agents. Working Papers, No. 12-21, Federal Reserve Bank of Philadelphia. Available at https://www.philadelphiafed.org/-/media/research-and-data/ publications/working-papers/2012/wp12-21.pdf
- Haldane A. (2018). How Monetary Policy Affects Your GDP. Finch Lecture, University of Melbourne, April 10, 2018. Available at https://www.bankofengland.co.uk/-/media/boe/ files/speech/2018/how-monetary-policy-affects-your-gdpspeech-by-andy-haldane.pdf

- Heathcote J., Perri F., Violante G. L. (2010). Unequal We Stand: An Empirical Analysis of Economic Inequality in the United States: 1967-2006. Review of Economic Dynamics, Vol. 13, No. 1, pp. 15-51. https://doi.org/10.1016/j. red.2009.10.010

- Heer B., Maussner A. (2012). The Burden OfUnanticipated Inflation: Analysis Of An Overlapping-Generations Model With Progressive Income Taxation And Staggered Prices. Macroeconomic Dynamics, Vol. 16, No. 2, pp. 278-308. https://doi.org/10.1017/S1365100510000490

lacoviello M. (2005). House Prices, Borrowing Constraints, and Monetary Policy in the Business Cycle. American Economic Review, Vol. 95, No. 3, pp. 739-764. https://doi.org/10.1257/0002828054201477

Jorgenson D. (1963). Capital Theory and Investment Behavior. American Economic Review, Vol. 53, No. 2, pp. 247-259.

Kaplan G., Moll B., Violante G.L. (2018). Monetary Policy According to HANK. American Economic Review, Vol. 108, No. 3, pp. 697-743. https://doi.org/10.1257/aer.20160042

- Ledoit O. (2011). The redistributive effects of monetary policy. ECON - Working Papers 044, Department of Economics, University of Zurich. Available at http://www. econ.uzh.ch/static/wp/econwp044.pdf

Luetticke R. (2017). Transmission of Monetary Policy with Heterogeneity in Household Portfolios. Working paper, Department of Economics, University College London. Available at https://www.dropbox.com/ s/22m9w42hzr6ykyw/Luetticke\%202017.pdf

Mundell R. (1963). Capital Mobility and Stabilization Policy under Fixed and Flexible Exchange Rates. The Canadian Journal of Economics and Political Science, Vol. 29, No. 4, pp. 475-85. http://doi.org/10.2307/139336

- Ohlsson H. (2017). The Distributional Effects of Monetary Policy. Speech, Swedish Trade Union Confederation, Stockholm, April 7, 2017. Available at https://www.riksbank. se/globalassets/media/tal/engelska/ohlsson/2017/tal_ ohlsson_170407_eng.pdf

- Tenreyro S., Thwaites G. (2016). Pushing on a String: US Monetary Policy Is Less Powerful in Recessions. American Economic Journal: Macroeconomics, Vol. 8, No. 4, pp. 43-74. https://doi.org/10.1257/mac.20150016

Tobin J. (1969). A General Equilibrium Approach To Monetary Theory. Journal of Money, Credit and Banking, Vol. 1, No. 1, pp. 15-29. http://doi.org/10.2307/1991374

- United States Office of Personnel Management (2017). Retirement Age \& Trend Analysis of the Executive Branch. Available at https://www.opm.gov/policy-data-oversight/ data-analysis-documentation/federal-employment-reports/ reports-publications/retirement-age-trend-analysis.pdf

Williamson S. D. (2008). Monetary Policy and Distribution. Journal of Monetary Economics, Vol. 55, No. 6, pp. 1038-1053. https://doi.org/10.1016/j.jmoneco.2008.07.001 


\section{APPENDIX A}

Figure 1. Wealth of patient households, by income group and generation
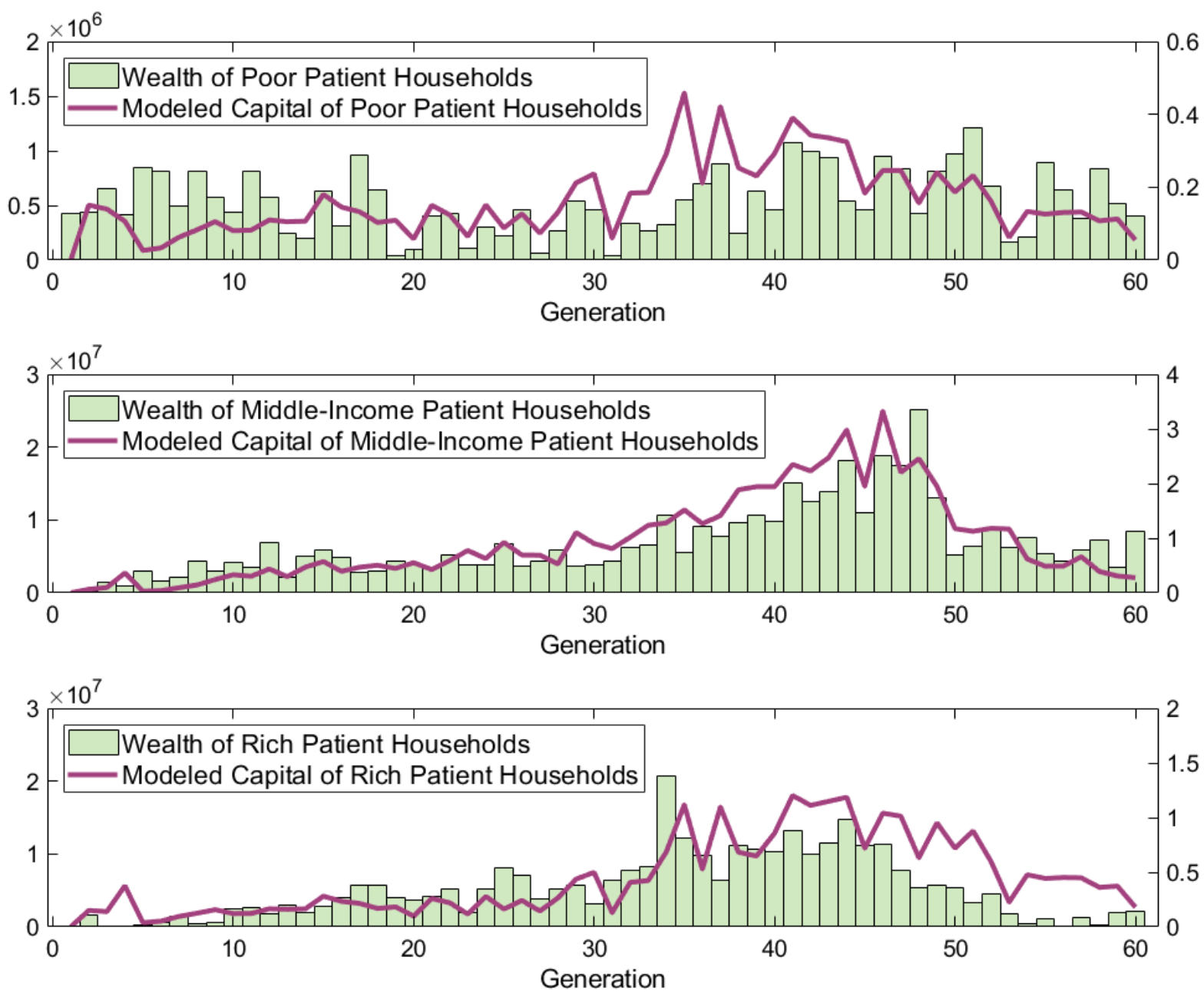
Figure 2. Wealth of impatient households, by income group and generation
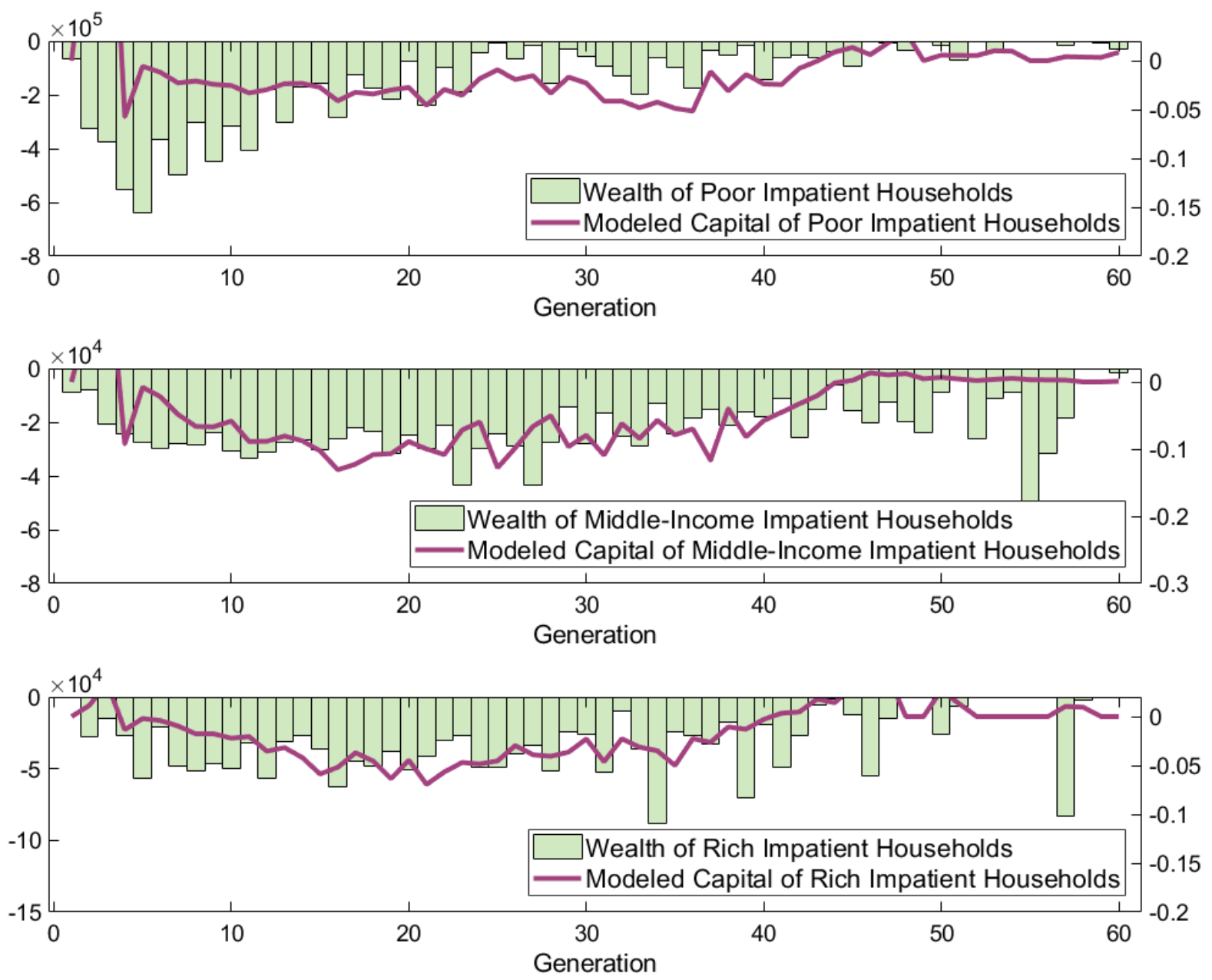
Figure 3. Idiosyncratic productivities of households

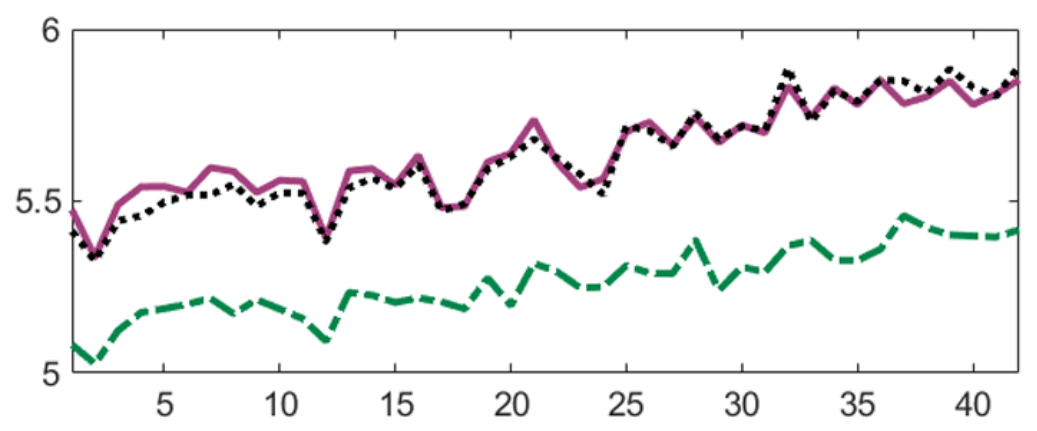

\begin{tabular}{|l|}
\hline -Poor Patient \\
---.-Poor Hand-to-Mouth \\
\hline
\end{tabular}

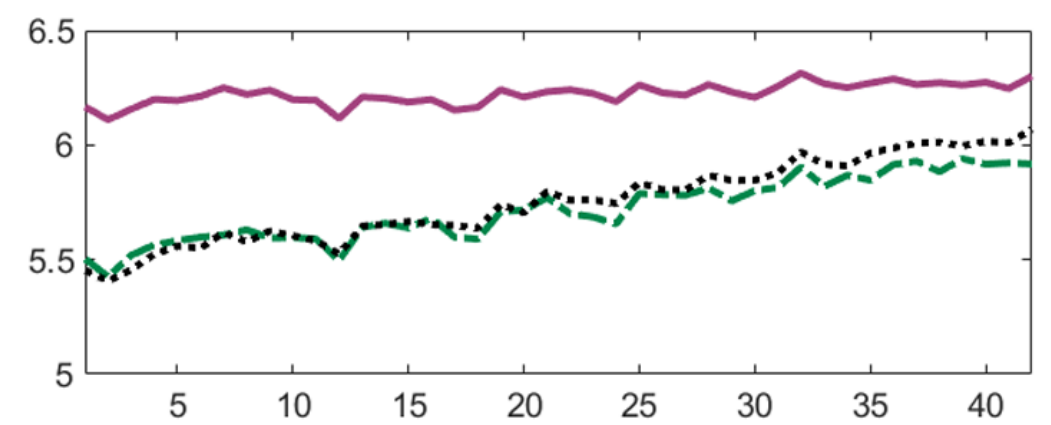

-Middle-Income Patient
---Middle-Income Hand-to-Mouth
.... Middle-Income Impatient

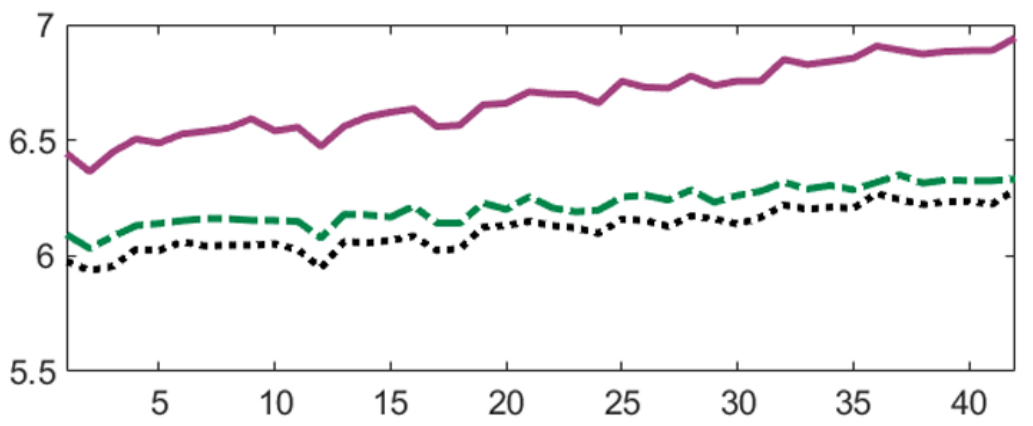

- Rich Patient

---Rich Hand-to-Mouth

..... Rich Impatient 
Figure A4. Responses of key macroeconomic variables
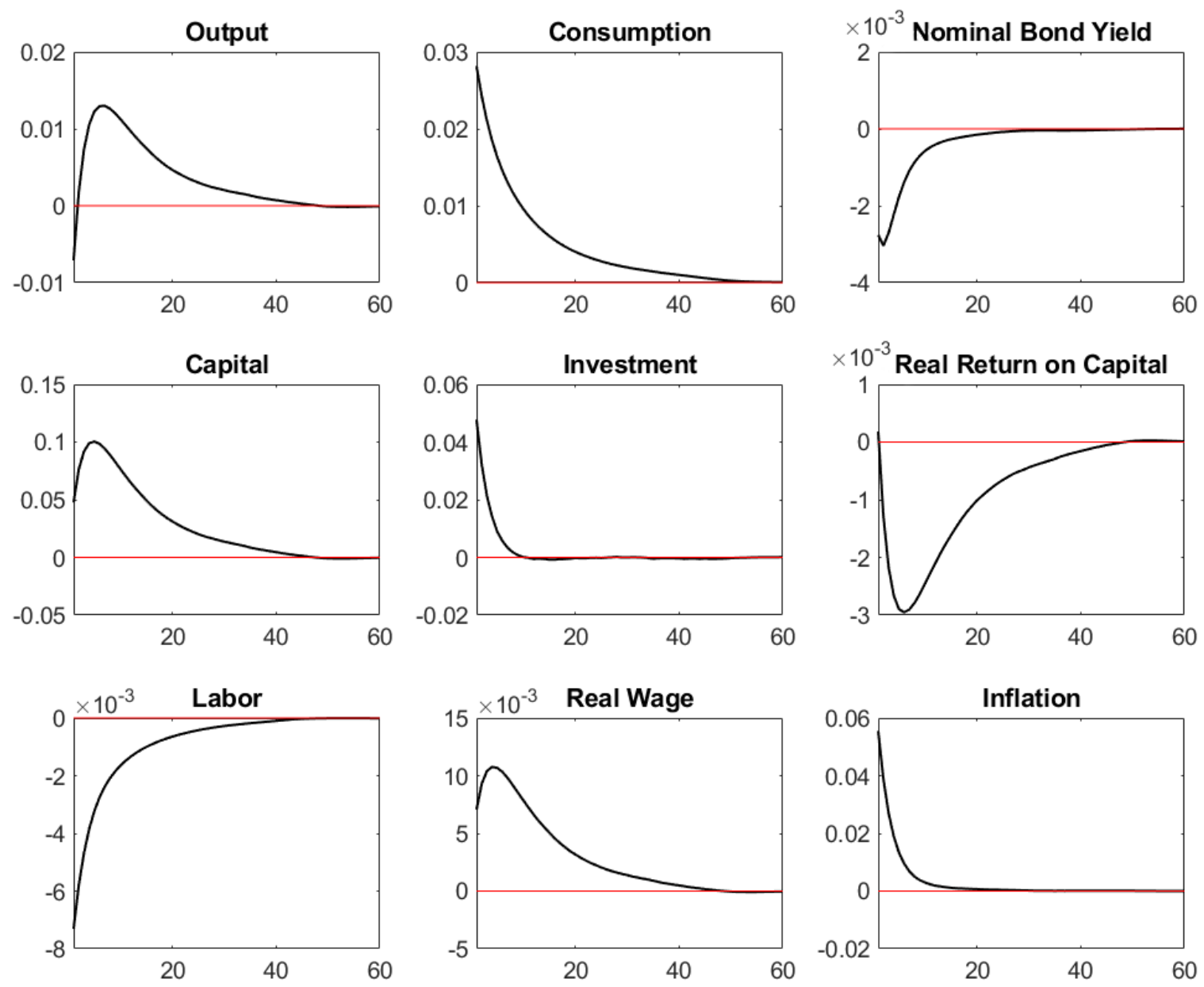